\title{
Peran Perkembangan Kegiatan Industri Dan Perdagangan Jasa Terhadap Perubahan Struktur Ruang KaWasan Solo Baru
}

\author{
Intan Dwi Astuti, Murtanti Jani Rahayu, Rizon Pamardhi Utomo \\ Program Studi Perencanaan Wilayah dan Kota, \\ Jurusan Arsitektur, Fakultas Teknik \\ Universitas Sebelas Maret, Surakarta \\ email: intanda13@gmail.com
}

\begin{abstract}
Solo Baru area is a satellite city that grew due to the phenomenon of urban sprawl in Surakarta. This area growth of more advanced and dominated by economic activity, especially industrial and trade-services activities. The problem is development on industrial and trade-services activities occur in Solo Baru certainly will encourage a change in the spatial area as centers of activities, patterns of land use and road network. Changes in the spatial aspect will have a negative impact on the regularity of the spatial structure and function of the area to the surrounding area. Therefore, this research was conducted to determine the role of the development of industrial and trade-services activities to the changes in the spatial structure of Solo Baru area. The method of research is deductive-quantitative, while the data analisys technique used is descriptive analysis of quantitative and spatial descriptive. The results of this study notes that both of industrial and tradeservices activities have developed from years 2002-2014 that occurred development of industrial activity by $43 \%$ and trade-services activities amounted to $140 \%$. The role of the development of industrial and trade-services activities include the agglomeration of activities and to encourage a change in the distribution centers that changes occur in the central-subcentral models that undergo a change from a non-centered to form multi-nodal. In addition, the industrial and trade-services activities also encourage land use changes and then give impact to the shift and functional zoning exist within the area as well as attract more movement leads to a change in the function and capacity of the road network.
\end{abstract}

Keywords: activity development role, industrial, spatial structure, trade-services

\section{PENDAHULUAN}

Kawasan Solo Baru merupakan kota satelit bagi perkotaan Surakarta untuk memenuhi kebutuhan akan tempat tinggal. Perkembangan Kawasan Solo Baru kini tidak hanya menjadi kota satelit saja akan tetapi sudah berkembang menjadi pusat kegiatan baru yang memiliki kedudukan sebagai PKLp (Pusat Kegiatan Lokal promosi) di dalam RTRW Kabupaten Sukoharjo. Fungsi pelayanan ini dikarenakan berkembangnya kegiatan kota terutama kegiatan perekonomian yang berkembang di sepanjang Jalan Ir. Soekarno bahkan oleh pemerintah Kabupaten Sukoharjo akan direncanakan sebagi kota mandiri.

Perkembangan kegiatan ekonomi perkotaan di kawasan ini cukup pesat dan beragam, terlihat dari besarnya tingkat pendapatan daerah regional bruto Kecamatan Grogol yang selalu meningkat setiap tahunya. Dalam kurun waktu tahun 2002 hingga tahun 2011, terdapat 3 jenis kegiatan ekonomi yang dominan berkembang di Kawasan Solo Baru yaitu industri pengolahan dan perdagangan serta jasa. Secara kontinyu setiap tahunnya, ketiga sektor tersebut, memberikan kontribusi sebesar $83 \%$ dari total pendapatan Kecamatan Grogol.

Dlihat dari perkembangan jumlah sarana perekonomian di Kawasan Solo Baru juga mengalami peningkatan yaitu menurut data Kecamatan Grogol Dalam Angka pada tahun 2005 jumlah sarana perekonomian ini adalah 576 unit kemudian pada tahun 2008 menjadi 872 unit dan mengalami penambahan yang signifikan pada tahun 2011 yaitu sebanyak 1911 unit. Dilihat terkait aspek guna lahan kawasan, dari data terakhir menunjukan guna lahan dominan kegiatan ekonomi adalah untuk industri seluas 222,77 $\mathrm{Ha}$ serta 
perdagangan-jasa seluas 77,6 Ha. Dengan kondisi di atas, Solo Baru saat ini lebih dikenal sebagai kawasan pusat bisnis dengan dominasi kegiatan industri dan perdagangan-jasa, walaupun berkembang pula kegiatan lain seperti perumahan dan fasilitas.

Persebaran kegiatan industri dan perdagangan-jasa semakin hari semakin rapat karena kegiatan sejenis yang mulai berdatangan memilih lokasi usahanya di sekitar kegiatan yang sudah berkembang. Kondisi ini akan semakin memperluas persebaran kegiatan industri dan perdagangan-jasa di Kawasan Solo Baru.

Di sisi lain, keberadaan kegiatan industri dan perdagangan-jasa di Kawasan Solo Baru ini secara keruangan akan membentuk suatu pola tertentu yang disebut struktur ruang. Struktur ruang merupakan susunan unsur-unsur pembentuk kawasan perkotaan yang secara hierarkis dan struktural saling berhubungan. Struktur ruang memiliki beberapa unsur yang saling mempengaruhi dan berhubungan satu sama lain sehingga kawasan perkotaan dapat berjalan sebagaimana mestinya.

Dari perkembangan kawasan yang terus menerus, masalah yang terjadi adalah perkembangan kegiatan industri dan perdagangan-jasa ini akan mempengaruhi bentuk struktur ruang kawasan di antaranya terkait pusat-pusat kegiatan, pola penggunaan lahan dan pola jaringan jalan. Perubahan yang terjadi pada aspek keruangan tersebut akan berdampak negatif pada keteraturan struktur ruang kawasan serta kedudukan dan fungsi Kawasan Solo Baru terhadap daerah di sekitarnya.

Selain itu, fenomena yang terjadi di lapangan dan menjadi isu kawasan ini adalah adanya perubahan unsur-unsur struktur ruang sehingga menyebabkan berubahnya bentuk struktur keruangan kawasan secara umum. Perkembangan kegiatan industri dan perdagangan-jasa akan mendorong perubahan pada unsurunsur pembentuk struktur ruang kota dengan menarik kegiatan sejenis maupun kegiatan perkotaan lainnya yang mendorong terjadinya perubahan tersebut.

Mengacu pada hal di atas, maka rumusan permasalahan dalam penelitian ini adalah bagaimanakah peran perkembangan kegiatan industri dan perdagangan-jasa terhadap perubahan struktur ruang Kawasan Solo Baru?

\section{METODE PENELITIAN}

Penelitian ini merupakan penelitian deskriptif dengan menggunakan pendekatan deduktif di mana dalam merumuskan variabel menggunakan teori sehingga diketahui kebutuhan data yang akan digunakan. Penelitian ini termasuk dalam penelitian studi kasus yang merupakan strategi penelitian di mana menurut Stake dalam Creswell (2010) di dalamnya peneliti menyelidiki secara cermat suatu program, peristiwa, kegiatan, proses atau sekelompok individu pada kondisi tertentu.

Konsep peran dalam penelitian ini adalah terkait kontribusi yang dilakukan terhadap suatu pekerjaan atau tugas/fungsi yang dimiliki terhadapnya. Untuk melihat peran antara satu hal terhadap hal lainnya dapat diartikan dengan melihat seperti apa kontribusi atau andil yang diberikan oleh satu hal tersebut terhadap hal lainnya.

Dalam pengumpulan data yang dibutuhkan dalam penelitian terbagi menjadi data primer dan data sekunder. Data primer didapatkan melalui observasi lapangan, wawancara dan kuesioner serta data sekunder didapatkan melalui studi dokumen/literatur dan interpretasi peta serta citra satelit.

Teknik analisis yang digunakan dalam penelitian ini secara garis besar menggunakan analisis secara deskriptif kuantitatif dan spasial. Penelitian ini merupakan penelitian studi kasus dengan metoda observasi langsung ke lapangan kemudian diproses menggunakan analisis deskriptif kuantitatif dan spasial. Analisis yang digunakan terdiri dari tiga tahapan yaitu:

1. Mengetahui perkembangan kegiatan industri dan perdagangan-jasa 20022014 dengan teknik analisis deskriptif kuantitatif dan spasial.

2. Mengetahui perubahan struktur ruang 2002-2014 dengan teknik analisis deskriptif kuantitatif dan spasial.

3. Mengetahui peran perkembangan kegiatan industri dan perdagangan-jasa 
terhadap perubahan struktur ruang dengan teknik analisis deskriptif spasial.

\section{HASIL DAN PEMBAHASAN}

\subsection{Analisis deskriptif kuantitatif} perkembangan kegiatan industri dan perdagangan-jasa

Analisis perkembangan kegiatan industri dan perdagangan-jasa dilihat dari lima indikator yaitu sebaran, jumlah unit usaha, luas lantai kegiatan, luas lahan dan jangkauan pelayanan yang dihitung perkembangannya dari tahun 2002-2014. Dari hasil analisis diketahui bahwa ratarata perkembangan kegiatan industri sebesar 43,05\% sedangkan rata-rata perkembangan kegiatan perdagangan-jasa sebesar 140,07\%. Perkembangan yang tertinggi untuk kegiatan industri adalah dari perkembangan luas lantai kegiatannya sedangkan kegiatan perdagangan-jasa memiliki perkembangan tertinggi dari perkembangan luas lantai kegiatan dan jangkauan kegiatannya.

Perkembangan kegiatan industri dan perdagangan-jasa di Kawasan Solo Baru pada tahun 2002-2014 apabila dilihat dari setiap indikatornya mengalami peningkatan yang sedang.

Perkembangan yang sangat tinggi adalah dari peningkatan luas lantai kegiatan kegiatan industri dan perdagangan-jasa yang mencapai hampir dua kali lipat, hal ini karena kegiatan yang muncul tidak hanya dibangun secara horizontal namun juga secara vertikal. Perkembangan jumlah unit usaha adalah sedang karena usaha baru yang muncul kebanyakan adalah usaha besar seperti pusat perbelanjaan dan perhotelan. Sedangkan untuk perkembangan luas lahan dan jangkauan kegiatan tergolong rendah. Secara keruangan perkembangan kegiatan industri dan perdagangan-jasa cenderung membentuk aglomerasi pada titik/area tertentu sehingga persebarannya tidak terlalu meluas (lihat peta lampiran).

\subsection{Analisis deskriptif kuantitatif} perubahan struktur ruang

Dari analisis ketiga unsur pembentuk struktur ruang yaitu pusat kegiatan, kawasan fungsional, dan jaringan jalan diketahui bahwa rata-rata perubahan struktur ruang yang terjadi di Kawasan
Solo Baru selama kurun waktu 12 tahun (2002-2014) adalah sebesar 35, 42\%. Perubahan yang terjadi hampir menyeluruh di kawasan namun yang paling terlihat adalah perubahan pusat kegiatan yaitu dengan penggabungan pusat-pusat kegiatan yang lebih besar di Jalan Ir. Soekarno.

Dari identifikasi pusat kegiatan yang telah dilakukan, pada tahun 2002 pusat kegiatan yang terbentuk adalah 11 pusat namun pada tahun 2014 pusat kegiatan yang terbentuk adalah 7 pusat kegiatan karena terjadi penggabungan beberapa pusat menjadi satu.

Selain itu terjadi perubahan kawasan fungsional karena alih fungsi lahan non komersil menjadi lahan komersil sebesar 143,71 Ha. Serta perubahan fungsi dan kapasitas jalan di sekitar pusat-pusat kegiatan yaitu terdapat empat ruas jalan yang mengalami perubahan fungsi adalah Jalan Sidomukti, Jalan TanjunganomBaki, Jalan Ir Soekarno dan Jalan Ciu, namun selain itu juga terdapat empat ruas jalan lainnya yang mengalami perubahan kapasitas.

3.3 Analisis deskriptif spasial peran perkembangan kegiatan industri dan perdagangan jasa terhadap perubahan struktur ruang

Analisis deskriptif spasial ini berdasarkan temuan perubahan keruangan di Kawasan Solo Baru (lihat peta lampiran).

Setelah melakukan dua analisis sebelumnya, kemudian dilanjutkan analisis peran untuk mengetahui bagaimanakah peran yang dimiliki oleh kegiatan industri dan perdagangan-jasa terhadap perubahan struktur ruang Kawasan Solo Baru. Analisis peran tersebut dijabarkan sebagai berikut:

1. Peran perkembangan kegiatan industri dan perdagangan-jasa terhadap perubahan pusat kegiatan

Zahnd (1999) berpendapat bahwa keberlanjutan kegiatan menyebabkan perkembangan fisik ruang kota dan secara langsung memiliki andil dalam perkembangan struktur ruang kota yang tidak pernah berhenti. Lebih lanjut, Parr (1999) menjelaskan bahwa konsentrasi / aglomerasi kegiatan perekonomian di pusat pertumbuhan terutama industri 
dan perdagangan-jasa memiliki keterkaitan ke depan (forwad linkage) dan kaitan ke belakang (backward linkage).

Keterkaitan tersebut di Kawasan Solo Baru ditunjukan dengan perkembangan kegiatan bahwa perkembangan kegiatan cenderung mengelompok di sekitar kegiatan lama sehingga terbentuk aglomerasi yang lebih besar yang menyebabkan perubahan pada pusat kegiatan kawasan. Berdasarkan kondisi di lapangan yang ada maka dapat ditarik suatu temuan bahwa dengan perkembangan kegiatan industri dan perdagangan-jasa di Kawasan Solo Baru berperan dalam perubahan pusatpusat kegiatan yaitu dengan mendorong terciptanya pusat kegiatan yang lebih besar baik dengan penggabungan beberapa pusat kegiatan maupun dengan perkembangan besaran pusat kegiatan dari yang sudah ada sebelumnya.

2. Peran perkembangan kegiatan industri dan perdagangan-jasa terhadap perubahan kawasan fungsional

Menurut Jayadinata (1999) setiap kegiatan terutama kegiatan ekonomi yang berkembang pasti memerlukan tanah atau ruang. Begitu pula dengan kegiatan industri dan perdagangan-jasa di Kawasan Solo Baru yang selalu berkembang akan membetuhkan lahan untuk menampung perkembangan tersebut serta kebutuhan lahan untuk kegiatan pendukung seperti perumahan, sehingga dengan perubahan yang terjadi dapat ditarik suatu temuan bahwa dengan perkembangan kegiatan industri dan perdagangan-jasa di Kawasan Solo Baru ini berperan dalam mendorong terjadinya alih fungsi lahan dari non komersil menjadi lahan komersil yang kemudian akan berimbas pada pergeseran luasan dan zonasi kawasan fungsional yang ada.

3. Peran perkembangan kegiatan industri dan perdagangan-jasa terhadap perubahan jaringan jalan
Dijelaskan oleh Rustiadi (2009)

bahwa perkembangan kegiatan seperti halnya kegiatan industri dan perdagangan-jasa yang kemudian membentuk pusat-pusat kegiatan akan menentukan bagaimana struktur jalan yang terbentuk untuk dapat menghubungkan antar pusat kegiatan tersebut. Perubahan jaringan jalan di Kawasan Solo Baru adalah terjadi di sekitar area yang didominasi oleh perkembangan kegiatan industri dan perdaganganjasa. Sehingga dapat ditarik temuan berdasarkan kondisi Kawasan Solo Baru bahwa perkembangan kegiatan industri dan perdagangan-jasa berperan dalam mendorong terjadinya peningkatan pergerakan yang akan merubah fungsi jaringan jalan yang ada sebelumnya.

Perkembangan kegiatan industri dan perdagangan-jasa terutama pada kota baru yang sedang tumbuh seperti di Kawasan Solo Baru adalah suatu hal yang pasti apalagi didukung pula oleh kebijakan pemerintah setempat. Serta dukungan lokasional Kawasan Solo Baru yang strategis dan telah memiliki pasar pemasaran, mendorong semakin berkembanganya kegiatan ini, yang mana kegiatan industri dan perdagangan-jasa ini dapat mendorong (memiliki peran) terhadap arah perkembangan kota maupun kawasan sekitarnya. Keberlanjutan kegiatan ini menyebabkan perkembangan fisik ruang kota dan secara langsung mempengaruhi perkembangan struktur ruang kota yang tidak pernah berhenti (Zahnd, 1999).

Di Kawasan Solo Baru kegiatan industri yang cenderung menempati bagian pinggir kawasan berperan dalam perubahan luasan area pusat kegiatan dan kawasan fungsional yang ditempatinya sedangkan kegiatan industri dan perdagangan-jasa yang cenderung menempati bagian tengah kawasan berperan dalam terbentuknya pusat kegiatan baru dan pembentukan pusat kegiatan besar yang merupakan 
gabungan dari beberapa pusat-pusat kecil. Selain itu jaringan jalan yang terdapat di sekitar perkembangan kegiatan industri dan perdagangan-jasa juga mengalami perubahan (peningkatan) fungsi dan kapasitas jalannya.

Analisis deskriptif spasial perubahan yang terjadi pada struktur ruang Kawasan Solo Baru ditunjukan dengan gambaran sebagai berikut:
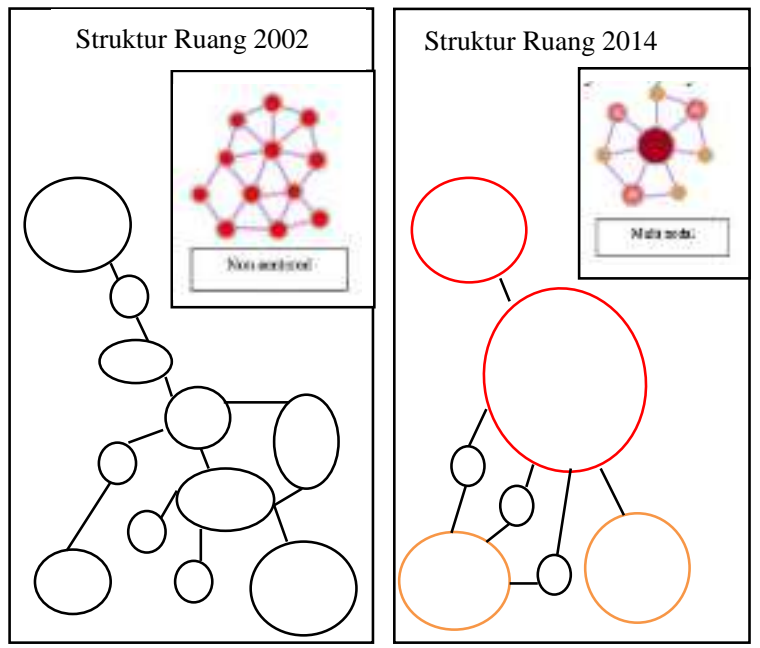

Gambar 1 Skematis perubahan Struktur ruang Kawasan Solo Baru

Berdasarkan penggambaran perubahan struktur ruang di atas, diketahui bahwa bentuk struktur ruang kawasan pada dasarnya tidak mengalami perubahan pola yaitu tetap berbentuk multiple nuclei. Hanya saja pusat yang terbentuk memiliki pola yang berbeda di mana pada tahun 2002 banyak terdapat pusatpusat kecil tanpa adanya pusat besar sebagai pusat kawasan yang merupakan model non-centered, sedangkan pada tahun 2014 terdapat pusat besar sebagai pusat kawasan yang merupakan model multi-nodal.

Perubahan bentuk struktur ruang di atas terjadi didorong oleh perkembangan dari indikator-indikator kegiatan industri dan perdagangan-jasa yang kemudian secara bertahap berperan dalam terjadinya perubahan struktur ruang Kawasan Solo Baru melalui perubahan yang ditimbulkan terhadap perubahan unsur-unsur struktur ruang. Baik dari perubahan pusat kegiatan, kawasan fungsional, dan jaringan jalan di mana dari ketiga unsur tersebut perubahannya terjadi di sekitar area yang terjadi perkembangan kegiatan industri dan perdagangan-jasa sehingga dapat dilihat bahwa kegiatan industri dan perdagangan-jasa merupakan faktor pendorong atau memiliki andil (berperan) terhadap perubahan struktur ruang yang terjadi.

Selain oleh perkembangan kegiatan industri dan perdagangan-jasa, perubahan struktur ruang kawasan juga didorong oleh beberapa kegiatan lain yang mana menurut Yunus (2000), kegiatan perkotaan yang dapat berperan dalam perubahan struktur fisik kota di antaranya adalah kegiatan ekonomi (selain industri dan perdagangan-jasa), sosial (fasilitas dan pelayanan umum), politik (pemerintahan) serta budaya. Di Kawasan Solo Baru sendiri kegiatankegiatan tersebut juga ada namun dilihat dari perkembangan yang ada tidaklah terlalu signifikan dalam berperan terhadap perubahan struktur ruang. Hal tersebut dikarenakan perkembangannya tidaklah sebesar kegiatan industri dan perdagangan-jasa baik dilihat dari jumlah maupun persebaran dan guna lahannya.

Di sisi lain perkembangan Kawasan Solo Baru juga didukung oleh kebijakan dan faktor lokasi kawasan yang strategis. Kawasan Solo Baru secara lingkup kewilayahan diapit oleh dua pusat pelayanan regional yang cukup besar yaitu Kota Surakarta di sebelah utara dan Perkotaan Kabupaten Sukoharjo di sebelah selatan.

\section{KESIMPULAN}

Kegiatan industri mengalami perkembangan yang tergolong dalam tingkat sedang dan kegiatan perdaganganjasa mengalami perkembangan yang tergolong dalam tingkat tinggi. Struktur ruang Kawasan Solo Baru mengalami perubahan yang tergolong dalam tingkat sedang pada masing-masing unsur pembentuknya. Perubahan ini secara bentukan keruangan terjadi pada model pusat-subpusat yang mengalami perubahan dari bentuk non-centered pada tahun 2002 
kemudian mengalami perubahan menjadi bentuk multi nodal pada tahun 2014.

Peran perkembangan kegiatan industri dan perdagangan-jasa terhadap perubahan struktur ruang kawasan adalah dengan menarik aglomerasi kegiatan sejenis dan fasilitas lain untuk berlokasi di Kawasan Solo Baru kemudian mendorong perubahan struktur ruang kawasan dengan membentuk pusat kegiatan baru yang lebih besar. Selain itu, perkembangan kegiatan industri dan perdagangan-jasa juga mendorong perubahan terhadap alih fungsi lahan dari fungsi pertanian dan lahan kosong menjadi fungsi kegiatan permukiman dan kegiatan komersil sehingga menjadikan perubahan pada fungsional kawasan. Peran selanjutnya dari perkembangan kegiatan industri dan perdagangan-jasa adalah mendorong meningkatnya pergerakan (bangkitan dan tarikan) di Kawasan Solo Baru yang pada akhirnya akan menyebabkan terjadinya perubahan pada fungsi dan kapasitas jaringan jalan yang ada.

\section{REFERENSI}

Creswell, John. 2010. Research Design Pendekatan Kualitatif, kuantitatif dan Mixed. Yogyakarta: Pustaka Pelajar

Jayadinata, Johara. 1999. Tata Guna Tanah dalam Perencanaan Perdesaan perkotaan \& Wilayah. Bandung: ITB

Parr, John B. 1999. Growth Pole Strategies in Regional Ecomomic Planning : A Restropective View. Part 1. Origins and Advocacy. Glasgow: Urban Studies University of Glasgow, Vol.36, No. 7, 1195-1215, 1999.

Rustiadi, Ernan, dkk. 2009. Perencanaan dan Pengembagan Wilayah. Jakarta: Yayasan Pustaka Obor Indonesia dan Crestpent Press

Yunus, Hadi. S. 2000. Struktur Tata Ruang Kota. Yogyakarta: Pustaka Pelajar

Zahnd, Markus. 2003. Perancangan Kota Secara Terpadu. Yogyakarta: Kanisius 


\section{LAMPIRAN}

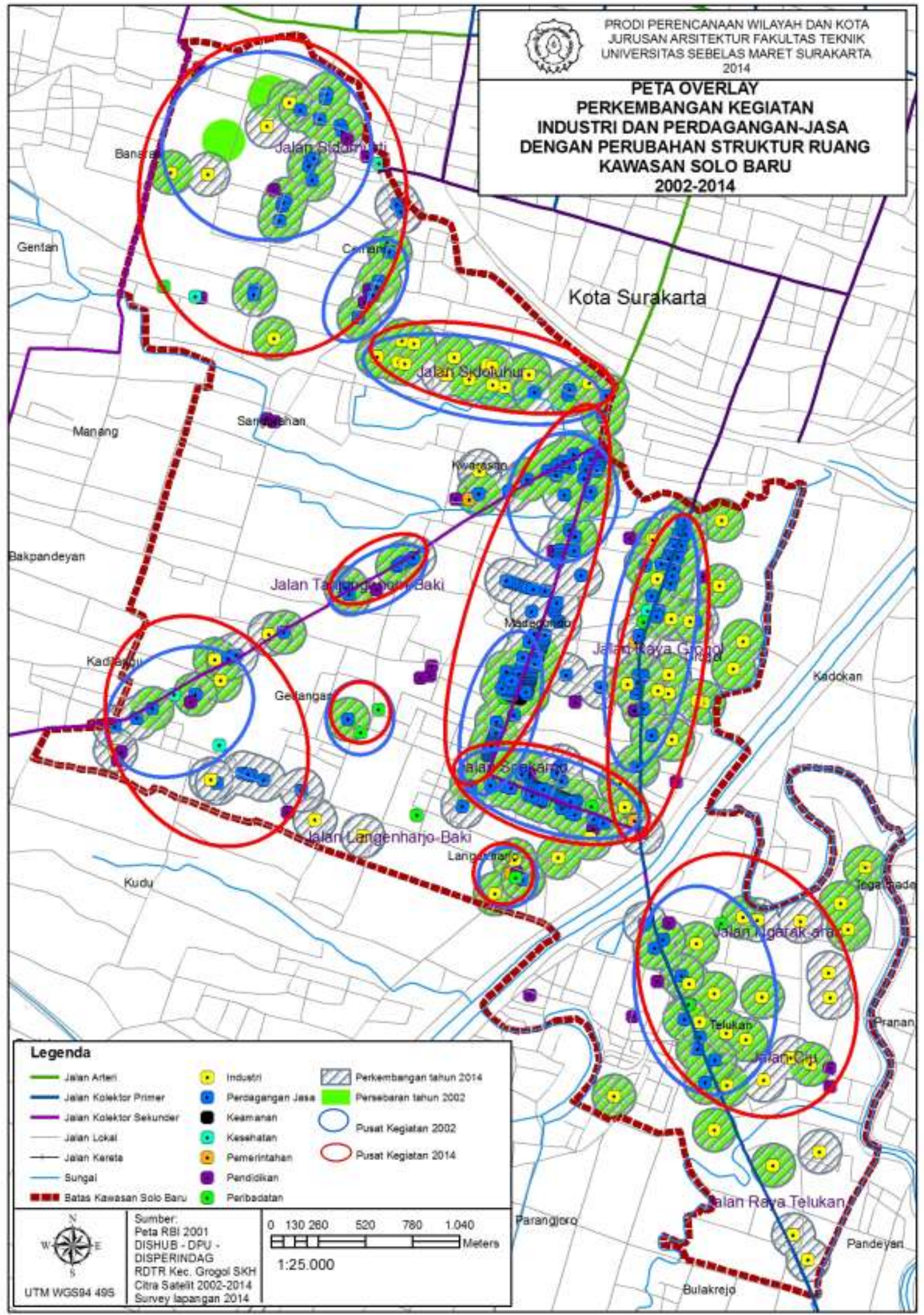

